\title{
Preliminary Research: Testing Talent Mapping Instrument for Top Secretary's Career Development
}

\author{
Selfiana ${ }^{1}$, Siti Rahmawati ${ }^{2}$, Asmara Soedomo ${ }^{3}$, Adrianus Trigunadi ${ }^{4}$ \\ \{selfianas@gmail.com ${ }^{1}$, wati.binainsani@gmail.com ${ }^{2}$, asmarasudomo@yahoo.com³ \\ adrianus_ts@yahoo.com ${ }^{4}$ \}
}

\begin{abstract}
Universitas Bina Insani, Jl. Raya Siliwangi No.6, Rawa Panjang, Bekasi ${ }^{1}$, Universitas Bina Insani, Jl. Raya Siliwangi No.6, Rawa Panjang, Bekasi² ${ }^{2}$ Universitas Bina Insani, Jl. Raya Siliwangi No.6, Rawa Panjang, Bekasi ${ }^{3}$, Universitas Bina Insani, Jl. Raya Siliwangi No.6, Rawa Panjang, Bekasi ${ }^{4}$
\end{abstract}

\begin{abstract}
This study contributes to develop Donald Super's and David C.McClelland's concepts. Career development is mainly influenced by behavior style, or personality type, or a set of habits that support effective and superior performance. The result of this study maps intrinsic competencies of top management's secretaries. These findings can be used to increase their potentials and develop their careers. It could also functions as a benchmark by employers in looking for a secretary that is engage do her role. A descriptive quantitative method is used in this study using a strength-based assessment tool called "talents mapping'. This assessment, classifies intrinsic strengths into four clusters namely influencing, relating, thinking and striving. There were thirty respondents with more than 3 years experiences being their top management's secretaries. The respondents showed that the dominant characteristics which excel within them are namely responsibility (53\%), consistency (50\%), developer $(50 \%)$, includer $(47 \%)$, and strategic $(40 \%)$.
\end{abstract}

Keywords: competency, talent mapping, secretary.

\section{Introduction}

Donald Super develops career through self concept, growth stages, and developing psychological role that builds one's various and vast career. A person needs to have a balance between his work and personal life as he undergoes different roles and life stages. Balance between all these roles is potential in increasing competencies and skills to develop ones career. Super emphasized on the importance of developing self concept that grows according to the work experience and position one holds [1]. An article examines David C.McClelland's pathbreaking paper: Testing for Competence Rather Than for "Intelligence"(1973) defined competency as an individual trait or set of habits that leads more to effective and superior work performance. A worker must show his competency in what he does. The best performance an employee can give is based on his personal characteristics which are called competencies [2]. According to Sorenson, Gallup has found that improving performance will be far more effective by building employees' strengths than trying to improve one's weaknesses. When 
employees know and use their strengths, they are more engaged, perform better, and are less likely to leave their company [3]. According to McClelland (1973) competencies are knowledge, skills, self-concept, traits and motives. Knowledge is information that a person has in a particular area. Skill is behavioral demonstration of expertise. Self-concept is attitudes, values, self image. Trait is a general disposition to behave in a certain way. Motives is recurrent thoughts that drive behavior [4].

Today's secretaries are not seen as only accomplishing administrative tasks, but also having opportunities to develop their potentials to transform themselves into creative and innovative workers. To catch up with the rapid changes and development of technology, companies require secretaries with excellent competencies. By having those competencies, they are expected to optimally contribute to the company. Result study on employees who use their strengths outperform those who don't is employees who use their strengths at work tend to be more productive because the activities and demands of their job are more intrinsically rewarding, which in tum leads them to work harder. Managers who use a strengths -based approach no longer waste time trying to wring adequate performance out of employees who are unsure if what they can contribute is making a difference [5].

The aim of this study is to identify competencies and dominant talent that a secretary must have in order to fully develop. A fully develop secretary will able to meet professional demand that is constantly rising. The competencies that are studied are those strongest, as well as what natural talents constantly merge from secretaries. The final aim of the study is to give a frame of reference in recruiting candidates and selecting the ones meeting employer's needs. As for the secretaries themselves, this study could be used as a means to understand their latent strengths and making thema base for future personaldevelopment.

Okoye studied the competencies of secretaries and revealed that manipulative, technology and communication competencies are required of secretary in the modern automated office. His study recommended, among others, that curriculum us ed for the training of secretaries be reviewed to integrate modern technologies and that secretaries should be encouraged to keep abreast of new technologies by availing themselves regularly of short training programs [6]. Study on strength-based development and its relationship to work engagement and performance examined by Van der Plas in 2016, showed that strength-based development enhances work engagement and in-role job performance. Furthermore, there was no support found to confirm that strength-based development enhances in-role job performance mediated by work engagement [7]. Study on required competencies in public administration study program examined by Janez Stare and Maja Klun in 2018, evaluated that the competencies related to ethics and ethical behavior were the most important and that generic competencies are better assessed than specific ones. They concluded that on average, competencies received a higher assessment for graduates compared to undergraduates positions [8].

\section{Methods}

The method of this research is quantitatif descriptive using talents mapping, a strength based assessment tool. Each respondent was required to do a self-assess ment. The tool consists of 170 statements reflecting all sorts of talents that have to be chosen between 5 options. Each 
option scales between strongly agree and strongly disagree. Between the 170 statements, 114 of them concem interest to their job which scales between very strong and very weak. This tool comes with a fully computerized result based on the respondents' answers. Scoring was computerized as well, and the assessment results were given in form of 34 talents organized in sequence with the dominant ones first and the least dominant last, in each talent theme. Dominant talent is reflected repeatedly in one's daily behavior, whereas the least ones are not.

The sample of 30 respondents as shown in table 1, are secretaries to top management level in their companies and were asked to fill-in and submit the questionnaires on line. The ans wers were computerized scored and then mapped and analyzed to identify the strengths and talents that are dominant to their profession.

\section{Result and Discussion}

This study mapped the strength that the respondents have by analyzing their 34 talents and then list them sequentially. The 34 talents are categorized in four clusters being influencing, relating, thinking, and striving. Each cluster projects how strong each talent influence one's character.

Table 1. Profile of Respondents.

\begin{tabular}{clr}
\hline No. & Position & Total \\
\hline 1 & Director's Secretary & 11 \\
2 & Vice President's Secretary & 5 \\
3 & General Manager' Secretary & 5 \\
4 & Human Capital's Secretary & 3 \\
5 & Group Head's Secretary & 2 \\
6 & Corp. Secretary's Secretary & 2 \\
7 & Company's Secretary & 1 \\
8 & Department's Secretary & 1 \\
& Total & 30 \\
\hline
\end{tabular}

Table 2. Business Sectors of Respondents.

\begin{tabular}{clr}
\hline No. & Business Sector & Total \\
\hline 1 & State-Owned Corporation & 10 \\
2 & Telecommunication Company & 7 \\
3 & Mechanical \& Electrical & 3 \\
& Company & \\
4 & Consumer Goods Company & 2 \\
5 & Oil Company & 2 \\
6 & Supplier Company & 2 \\
7 & Automotive Company & 1 \\
8 & Education Company & 1 \\
9 & Hospitality Company & 1 \\
10 & Manufacture Company & 1 \\
& Total & 30 \\
\hline
\end{tabular}




\subsection{Influencing Cluster}

Influencing is an individual talent which shows the individual's capability in influencing others. Table 2 shows the result of the influencing clus ter of the respondents.

Table 3. Result for Influencing Cluster.

\begin{tabular}{clrrr}
\hline No. & Competency & 5 Dominant & 7 Dominant & Non Dominant \\
\hline 1 & WOO & $10 \%$ & $10 \%$ & $43 \%$ \\
2 & Communication & $20 \%$ & $27 \%$ & $20 \%$ \\
3 & Self Assurance & $0 \%$ & $0 \%$ & $53 \%$ \\
4 & Significance & $10 \%$ & $10 \%$ & $27 \%$ \\
5 & Maximizer & $10 \%$ & $17 \%$ & $10 \%$ \\
6 & Competition & $0 \%$ & $0 \%$ & $87 \%$ \\
7 & Activator & $3 \%$ & $7 \%$ & $43 \%$ \\
8 & Command & $13 \%$ & $20 \%$ & $30 \%$ \\
\hline
\end{tabular}

Their most dominant influencing talents are communication, command and maximizer. The ability to communicate, both in choosing vocabularies and using the right gestures, play a big role in making others understand the message being transferred and supports them to achieve their aims. Having the courage to take up responsibility and challenge as well as their love of perfection that is oriented to high quality work are also dominant characteristics. Nevertheless, uncompetitive and unsure attitudes in facing uncertain situations are their limitations.

\subsection{Relating Cluster}

Relating is a talent that reflects the ability in building relationship or in working in teams. For this cluster, the result is as shown in table 3 .

Table 4. Result for Relating Cluster.

\begin{tabular}{clrrr}
\hline No. & Competency & 5 Dominant & 7 Dominant & Non Dominant \\
\hline 1 & Empathy & $7 \%$ & $7 \%$ & $20 \%$ \\
2 & Connectedness & $27 \%$ & $33 \%$ & $0 \%$ \\
3 & Individualization & $3 \%$ & $3 \%$ & $33 \%$ \\
4 & Adaptability & $10 \%$ & $17 \%$ & $13 \%$ \\
5 & Harmony & $3 \%$ & $20 \%$ & $7 \%$ \\
6 & Includer & $33 \%$ & $47 \%$ & $3 \%$ \\
7 & Relator & $30 \%$ & $33 \%$ & $10 \%$ \\
8 & Developer & $40 \%$ & $50 \%$ & $0 \%$ \\
9 & Positivity & $17 \%$ & $23 \%$ & $27 \%$ \\
\hline
\end{tabular}

Their main characteristics are the motivation to support others to develop and to reach success as well as a high sense of belonging. Respondents realize the benefit of group support in creating a sense of security in accomplishing their tasks. That is why their support to others in their group is high. Within the respondents, the ability to identify other persons' characteris tics is not their main talent. Other than that, having overly enthusiasm and cheerfulness are not considered as required by their job. 


\subsection{Cluster Thinking}

Thinking is an individual talent in one's ability to think. The respondents' result for this clusteris shown in table 4.

Table 5. Result of Thinking Cluster.

\begin{tabular}{clrrr}
\hline No. & Competency & 5 Dominant & 7 Dominant & Non Dominant \\
\hline 1 & Futuristic & $10 \%$ & $17 \%$ & $23 \%$ \\
2 & Strategic & $30 \%$ & $40 \%$ & $3 \%$ \\
3 & Ideation & $10 \%$ & $17 \%$ & $3 \%$ \\
4 & Analytical & $20 \%$ & $33 \%$ & $3 \%$ \\
5 & Learner & $13 \%$ & $23 \%$ & $0 \%$ \\
6 & Input & $13 \%$ & $20 \%$ & $7 \%$ \\
7 & Intellection & $3 \%$ & $7 \%$ & $40 \%$ \\
8 & Context & $0 \%$ & $0 \%$ & $60 \%$ \\
\hline
\end{tabular}

The ability to think strategically that orients to short and medium terms solution, together with critical attitude in handling information or request stood out in the respondents. This is an important factor in their career development. On the contrary, their habits to contemplate on a subject are not expected in their job because their work places require immediate actions that are result oriented.

\subsection{Striving Cluster}

Striving is a motivation deriving from within the self and is not influenced by external factors. Striving cluster's result is shown in table 5 .

Table 6. Result of Thinking Cluster.

\begin{tabular}{llrrr}
\hline No. & Competency & 5 Dominant & 7 Dominant & Non Dominant \\
\hline 1 & Restorative & $0 \%$ & $0 \%$ & $60 \%$ \\
2 & Deliberative & $20 \%$ & $30 \%$ & $17 \%$ \\
3 & Arranger & $3 \%$ & $10 \%$ & $7 \%$ \\
4 & Discipline & $23 \%$ & $27 \%$ & $3 \%$ \\
5 & Consistency & $40 \%$ & $50 \%$ & $3 \%$ \\
6 & Focus & $7 \%$ & $13 \%$ & $17 \%$ \\
7 & Achiever & $7 \%$ & $10 \%$ & $13 \%$ \\
8 & Responsibility & $50 \%$ & $53 \%$ & $0 \%$ \\
9 & Belief & $13 \%$ & $27 \%$ & $13 \%$ \\
\hline
\end{tabular}

The most prominent characteristic in this striving intrinsic motivation cluster is their attitude of high responsibility and commitment in doing their jobs which impact to the task accomplishment no matter what effort it takes. Because of these characteristics, professional credibility and self reputation is prominent. In executing their tasks, respondent highly prioritize conformity to the prevailing rules and regulation which is why they love task with clear SOPs. Besides that, they are more attentive to being cautious in execution any tasks. Respondents do not like task involving revision or improvement so that is why they have the tendency to achieve impeccable results. Based on the above data, we summarize the sequence of competency possessed by the top secretaries in table 6 and 7 . 
Table 7. Sequence of Competency Based on 5 Dominant

\begin{tabular}{ccc}
\hline Sequence & Competency & $\%$ \\
\hline 1 & Responsibility & $50 \%$ \\
2 & Developer & $40 \%$ \\
3 & Consistency & $40 \%$ \\
4 & Includer & $33 \%$ \\
5 & Strategic & $30 \%$ \\
6 & Relator & $30 \%$ \\
7 & Connectedness & $27 \%$ \\
8 & Discipline & $23 \%$ \\
9 & Deliberative & $20 \%$ \\
10 & Analytical & $20 \%$ \\
11 & Communication & $20 \%$ \\
12 & Positivity & $17 \%$ \\
13 & Learner & $13 \%$ \\
14 & Input & $13 \%$ \\
15 & Belief & $13 \%$ \\
16 & Command & $13 \%$ \\
17 & WOO & $10 \%$ \\
18 & Significance & $10 \%$ \\
19 & Maximizer & $10 \%$ \\
20 & Adaptability & $10 \%$ \\
21 & Futuristic & $10 \%$ \\
22 & Ideation & $10 \%$ \\
23 & Focus & $7 \%$ \\
24 & Achiever & $7 \%$ \\
25 & Empathy & $7 \%$ \\
26 & Intellection & $3 \%$ \\
27 & Harmony & $3 \%$ \\
28 & Arranger & $3 \%$ \\
29 & Individualization & $3 \%$ \\
30 & Activator & $3 \%$ \\
31 & Competition & $0 \%$ \\
32 & Self Assurance & $0 \%$ \\
33 & Context & $0 \%$ \\
34 & Restorative & $0 \%$ \\
\hline & &
\end{tabular}

Table 8. Sequence of Competency Based on 7 Dominant

\begin{tabular}{ccc}
\hline Sequence & Competency & $\%$ \\
\hline 1 & Responsibility & $53 \%$ \\
2 & Developer & $50 \%$ \\
3 & Consistency & $50 \%$ \\
4 & Includer & $47 \%$ \\
5 & Strategic & $40 \%$ \\
6 & Connectedness & $33 \%$ \\
7 & Relator & $33 \%$ \\
8 & Analytical & $33 \%$ \\
9 & Deliberative & $30 \%$ \\
\hline
\end{tabular}




\begin{tabular}{ccc}
\hline 10 & Communication & $27 \%$ \\
11 & Discipline & $27 \%$ \\
12 & Belief & $27 \%$ \\
13 & Positivity & $23 \%$ \\
14 & Learner & $23 \%$ \\
15 & Command & $20 \%$ \\
16 & Harmony & $20 \%$ \\
17 & Input & $20 \%$ \\
18 & Maximizer & $17 \%$ \\
19 & Adaptability & $17 \%$ \\
20 & Futuristic & $17 \%$ \\
21 & Ideation & $17 \%$ \\
22 & Focus & $13 \%$ \\
23 & WOO & $10 \%$ \\
24 & Significance & $10 \%$ \\
25 & Arranger & $10 \%$ \\
26 & Achiever & $10 \%$ \\
27 & Activator & $7 \%$ \\
28 & Empathy & $7 \%$ \\
29 & Intellection & $7 \%$ \\
30 & Individualization & $3 \%$ \\
31 & Self Assurance & $0 \%$ \\
32 & Competition & $0 \%$ \\
33 & Restorative & $0 \%$ \\
\hline
\end{tabular}

On the whole, the characteristics of the respondents that stood up are attitudes with high responsibility, supportive to reaching success of their directors or colleagues, conformity to SOPs, and capability to think strategically. On the contrary, they do not like working environment with rivalry and competition, tasks that are repetitive due to errors or mistakes, as well as tasks that need deepcontemplation.

\section{Conclusion}

Excellent competencies that are well developed by these top management's secretaries could be shaped because of their dominant productive traits of responsibility, consistency, developer, strategic, and includer. Those competencies could be increased through enhancing skills in activities of the said dominant talents. Combining intrinsic with extrinsic competencies will result to excellence in performance.

This study precedes more researches of top management's secretaries. Future research will investigate respondents' type and organization level in order to reach a general conclusion. 


\section{References}

[1] D. E. Super, "Super, D. E. (1980). A Life-Span, Life-Space Approach to Career Development. Journal of Vocational Behavior, 16, 282-298. A Life-Span, Life-Space Approach to Career Development," J. Vocat. Behav., vol. 16, pp. 282-298, 1980.

[2] V. S. Chouhan and S. Srivastava, "Understanding Competencies and Competency ModelingA Literature Survey," IOSR J. Bus. Manag., vol. 16, no. 1, pp. 14-22, 2014.

[3] Susan Sorenson, “How employee's Strength Make Your Company Stronger,” Bus. J., 2014.

[4] N. Vazirani, "Competencies and Competency Model - A Brief Overview of its Development and Application," SIES J. Manag., vol. 7, no. 1, pp. 121-131, 2010.

[5] F. Peter, J. Asplund, and G. Elliot, "Study On Employees Who Use Their Strengths Outperform Those Who Don't," Gall. Work., 2015.

[6] A. Okoye, "Professional Competencies Required of Secretaries in Moderns Automated Offices in Tertiary Institutions in Anambra State of Nigeria," J. Arts Manag. Soc. Sci., vol. 1, no. 1, pp. 89-97, 2016.

[7] F. Van der Plas, "Strength Based Development and Its Relationship to Work Engagement and Performance," 2016.

[8] J. Stare and M. Klun, "Required Competencies in Public Administration Study Programs," Transylvanian Rev. Adm. Sci., vol. 14, no. 55, pp. 80-97, 2018. 